\title{
Revealing strategies for the green heritage of Istanbul - the case of historical groves
}

\author{
E. Tekeli \& F. A. Turer Baskaya \\ Department of Landscape Architecture, \\ Istanbul Technical University, Turkey
}

\begin{abstract}
With a history dating back to $6000 \mathrm{BC}$, Istanbul has always been a significant city, standing on two continents separated by a strait called Bosphorus. Istanbul is a dynamic and ever-changing city which brings about rapid changes on historical green network. As one of the most important components of this green network, historical groves are open to overwhelming changes. The rapid urbanization and differentiation of land-use have yielded adverse impacts on the identity of the Bosphorus and historical landscape features. Due to the deficiencies in the management of heritage landscapes, alterations within the green network emerge which are not only spatial but also conceptional. Within that context, the questions that guide this paper are: What is the meaning of 'grove' for Istanbul? What are the spatiotemporal changes related with these groves within the Bosphorus area? What should be the sustainable landscape planning strategies for these green heritages? Seeking answers to these questions, this paper examines spatiotemporal changes throughout the Ottoman times to today, benefitting from various Ottoman maps dating back to 1764 . In order to gain a multi-layered understanding, this paper supports these map-based studies with credible literatures and field study. Reading the interplay between green heritage, historical coastal areas, urban development, and sustainable landscape planning reveals the prospected landscape planning strategies for the green heritages of Istanbul. This paper is an attempt to notice landscape planning strategies for urban green heritages and encourage further studies not only for the benefit of Istanbul, but also for the other dynamic mega cities.
\end{abstract}

Keywords: historical groves, green heritage, Bosphorus, landscape planning. 


\section{Introduction}

With a history dating back to $6000 \mathrm{BC}$, Istanbul has always been a significant city, standing on two continents separated by a strait called Bosphorus [1]. Bosphorus Strait is the one of the most important components of Istanbul's identity with its natural and cultural features [1].

Holding a population of $14,160,467$, the coastal megacity of Istanbul covers a vast area of 5,343 square kilometers [2]. Being capital of several empires, Istanbul has been developed as a major industry, commercial and cultural center since ancient times. Its coastal identity and Bosphorus did have a definite impact on its glorious history (Figure 1).

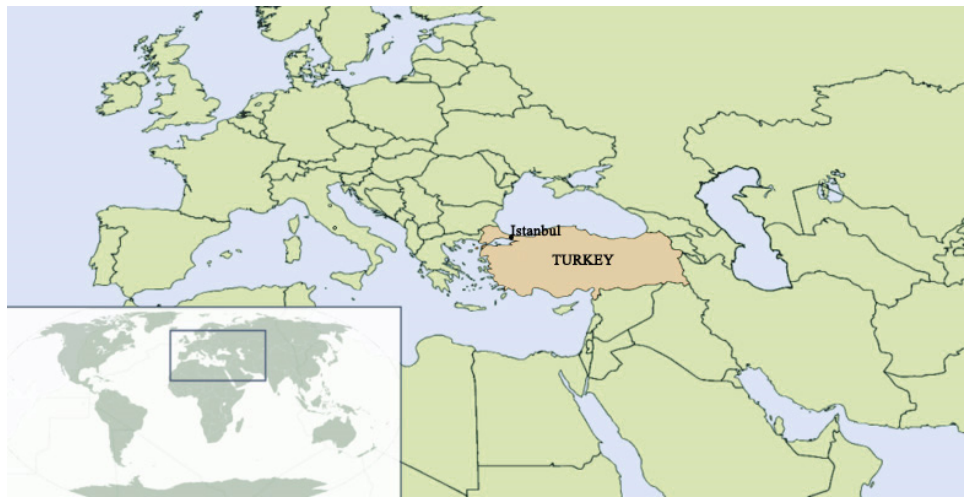

Figure 1: $\quad$ Location of Istanbul.

Bosphorus is a strategic waterway binding the Black Sea to the Sea of Marmara. Throughout the centuries, it has been used as a passage between Black Sea to Mediterranean, besides a bridge between Asia to Europe.

Bosphorus coastal area stands on separate continents with parallel bays and capes around the waterway. It holds diverse but interlinked microclimate and vegetation areas, dispersed to the topography. Outstanding morphology of Bosphorus has brought about a unique residential and cultural structure in harmony with the natural characteristics [3].

Within the last decades, worldwide urban expansion and built-up space increase bring about a demand for multi-functional use of current open spaces. Within this tendency, urban groves have been revealed through various international studies.

Grove is a tree dominant protected green area inside or in vicinity of the city. Grove can be a piece of a forest which is more or less separated from the major forest mass while it can also be a tree dominant and enclosed part of a city park [4].

Forestry based issues such as generation techniques of the vegetation cover do not matter in the case of urban groves. Protection process and the potential for providing recreational services are the main measures for urban groves [4]. 
Historical groves were usually established as the large gardens of the palaces, mansions and waterside residences. In Turkey, historical groves are usually located in Istanbul and they were established by the state or the owners of the relevant buildings [4].

Throughout the centuries ownerships of the Bosphorus groves have been more or less changed. Today Bosphorus holds private, semi-private and public groves with varying protection measures.

European Landscape Convention, which is ratified by Turkey, underlines the significant role of landscape for cultural, ecological, environmental and social services. It defines landscape as a basic component of European natural and cultural heritage and underlines its capacity to hold both local and European identity.

Within this study, green heritage refers to natural and cultural heritages that are subject to landscape planning and design studies. Examining Bosphorus through cultural landscape concept refers to the interplay between natural and cultural settings. Bosphorus consolidates a spatial network representative for the interplay between Ottoman landscapes' natural and cultural components.

In this context, Bosphorus groves are one of the cultural and natural heritage features in Istanbul. Groves of Istanbul are like palimpsest as the city was capital of several empires. Thus, importance of the historical groves still continues from Ottoman to today. There are lots of hard landscape and soft landscape elements and some structures (e.g. palaces, mansions etc.) in them. All these units capture symbolic meanings and constitute the vernacular landscape of the Bosphorus. Most of the groves hold the names of Ottoman Pashas or Ottoman dynasty members while some of the groves have consulate names as they are the belongings of the consulates. In addition, some of the groves are the courtyards of the Ottoman palaces, and they gain more values with their monumental structures on the characteristics topography of the Bosphorus.

\section{Material and methods}

This study aims to develop regenerative landscape planning strategies for urban green heritages of Bosphorus by gaining a multi-layered understanding of the interplay between historical green network and urban development. Within this context, this study handles Bosphorus groves which are located in the Front View Zone of Bosphorus Protected Area (Figure 2). These historical groves are selected as case studies, regarding their notable landscape features in the urban memory and Bosphorus identity. Groves handled with in this study are: Consulate Groves of Russia, England, France, Poland, Germany, Austria-Hungary Grove, Presidency Grove, Huber Grove, Sait Halim Pasha Grove, Misbah Grove, Emirgan Grove, Bogazici University Grove, Ipar Kortel Grove, Robert College Grove, Seyh-ul Islam Grove, Fethipasha Grove, Uryanizade Grove, Vanikoy Grove, Cemile Sultan Grove, Amcazade Grove, Hidiv Grove, Abrahampasha Grove, Beykoz Grove. 


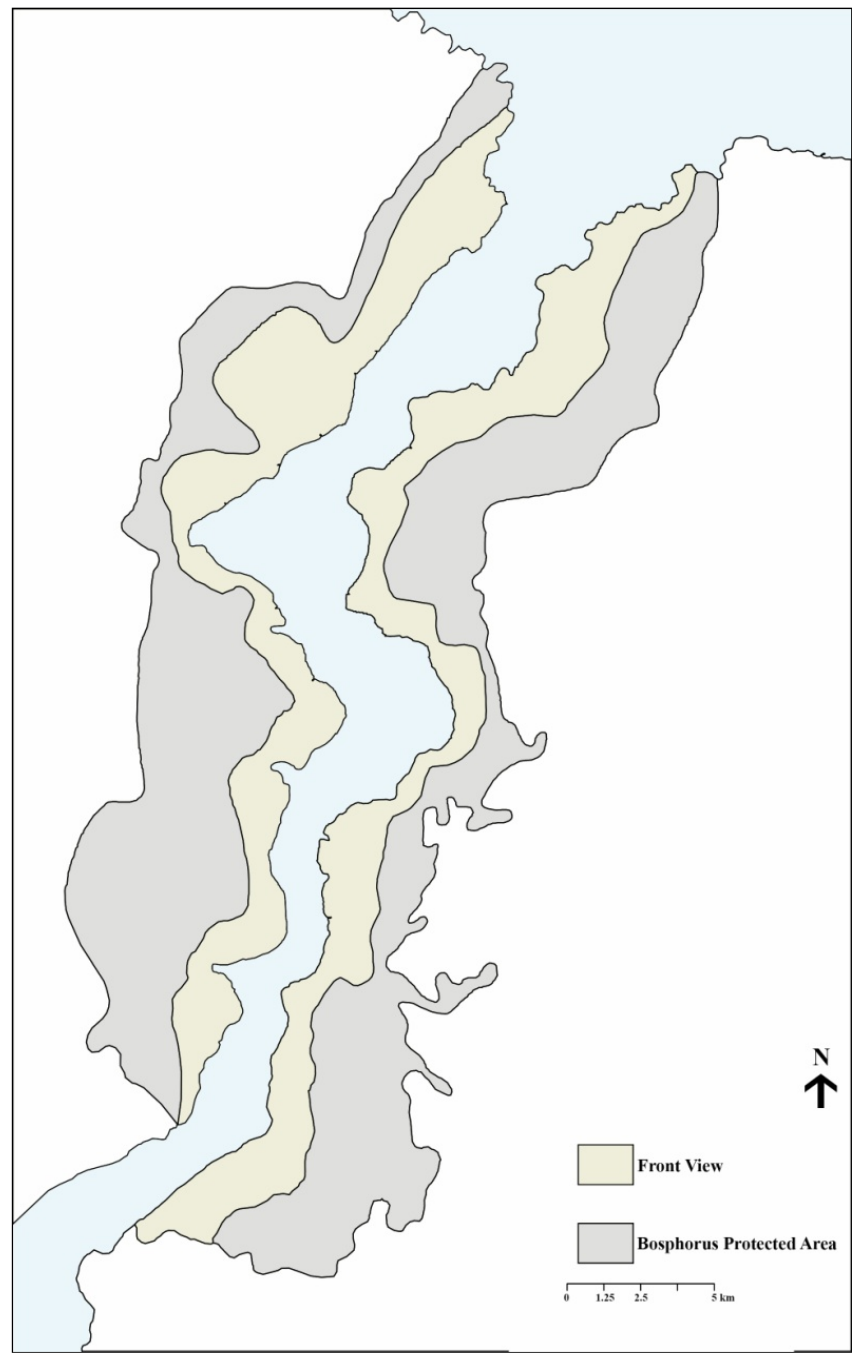

Figure 2: $\quad$ Bosphorus protected area.

The rapid urbanization and differentiation of land-use have yielded adverse impacts on the identity of the Bosphorus and historical landscape features. Due to the deficiencies in the management of heritage landscapes, alterations within the green network emerge which are not only spatial but also temporal. Studying on the alterations within the green network on the Bosphorus area, mapping technique is significant. It is required for examining the differentiation of land use on Bosphorus area from 1764 to today. This technique reveals the changes of the green heritages. Initially, groves and green areas are identified through

Ottoman dated maps. Ottoman maps and several maps belonging to Turkish Republic Period are superimposed with each other. Therefore spatial information 
pertinent to Bosphorus is gathered from several Ottoman dated maps (such as German Blues, Necip Bey maps, Perwititch maps), Republic Period maps, aerial photographs and current land-use maps. Conceptual part of this study benefits from old photographs together with the scholarly and government literature.

\section{Results and discussion}

During the Ottoman Period, vast green areas with dense vegetation were apparent in Istanbul. A combination of forests, meadows and agricultural areas constituted the huge green areas of the Ottoman capital city.

Figure 3 illustrates the dispersion of built-up areas and green areas in Istanbul of 1764 . The dense built-up space of the historical peninsula and the continuity of green areas along the Bosphorus are visible within this map. Today few green areas extending along the Bosphorus are the remnants of these vast green areas (Figure 4).



Figure 3: $\quad$ Bosphorus map by Johann Baptist von Reben, 1764 [5]. 


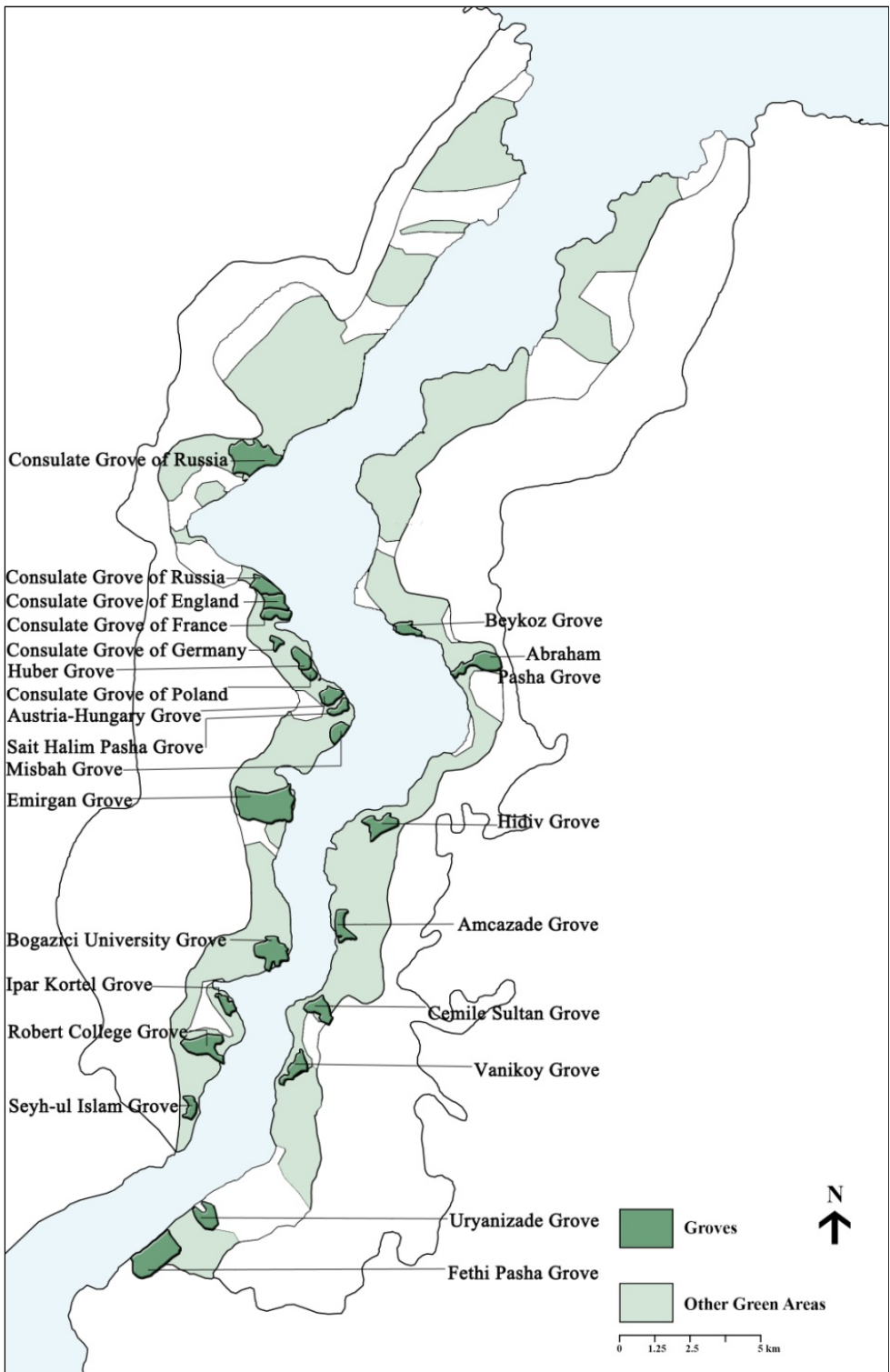

Figure 4: $\quad$ Land use map, 1764.

During the Ottoman Period, groves were holding state-owned palaces, hunting lodges, official buildings such as military schools, private mansions and mesire sites. These areas were rigged with macro to micro scale landscape elements, carrying characteristics of the relevant periods.

"Green structure of the Bosphorus embraces both natural and cultural vegetation cover. Undoubtedly, each of them contributes pretty much to the 
established identity" [1]. Pamay (as cited in [6]) indicates that the natural vegetation cover of the Bosphorus shows a transition between the Mediterranean climatic type to Black Sea climatic type. The natural vegetation cover is made up of forests and pseudo-machi's. The groves' texture is quite rich in terms of species ranging from shrubs to trees. Among this rich plant texture, some of the tree species appear to be Oak (Qerrcus), Chestnut (Castanea), Elm (Ulmus), Linden (Tilia), Ash (Fraxinus), Mastic Tree (Pistachio), Judas Tree (Cercis), Pine Tree (Pinus) and Cypress (Cupressus).

"Apart from the natural vegetation cover there are other vegetation types that have perfectly acclimatized in time in Bosphorus" [1]. Defining them as cultural vegetation, they are as important as the natural ones for the establishment and continuity of the Bosphorus vegetative identity. Thus, combination of Cypress (Cupressus semprevirens), Judas (Cercis siliquastrum) and Pine (Pinus Pinea) trees is symbolic for the well-known Bosphorus vegetation.

Following to the decadence of the Ottoman Empire and the World War II, new constructions occurred in the Bosphorus area, and multi-storey buildings took the place of wooden structures and green areas.

The 1950s were an important turning point for Istanbul due to the industrialization and the accompanying immigration which brought about rapid urban development. With this period, Bosphorus began to examine industrial buildings, cooperative houses and even squatters.

After built-up space increase in Bosphorus due to the rapid urbanization during the Republic Period, transportation based problems brought about the construction of Bosphorus Bridge in 1973. The Bosphorus Bridge stimulated green corridors' weakening, and gradually Bosphorus area got a fragmented landscape (Figure 5).

Partial protection plans and decisions relevant to Bosphorus area started at the 1950s. However, they were not capturing the area in unity with all of its features. Therefore, the 1970s were a turning point for Bosphorus due to the number of attempts to protect it.

First decision taken to protect the historical pattern of Bosporus area was relevant to the Istanbul Bosporus Waterside Mansions in which Real Estate Historical Buildings and Monuments Council played an active role. In 1971, 1/5000 scale "Bosporus Waterside Protection Plan" was prepared for arranging the settlement through the Bosporus and to protect the current waterside mansions. In 1973, the construction practices for Bosporus got under the control of Real Estate Historical Buildings and Monuments Council which generated provisions not only considering the settlement situation of Bosporus but also for protection of its specific green network [7]. Following to this administrative change, in 1974, the decisions related to Protection of Bosporus Woods and Plantations have been finally taken [8].

Insufficiency of a 1/5000 scale regional plan of 1977 brought about the preparation of the well-known plan of 1982 which has separated the Bosporus area to four zones as Waterside and Front View Zones (4300 ha), Back View Zone (1000 ha) and Effect Zone (5300 ha) [4]. The plan has defined the Bosporus area as a recreation, tourism and residence area and aimed to protect the green areas with varying measures. 


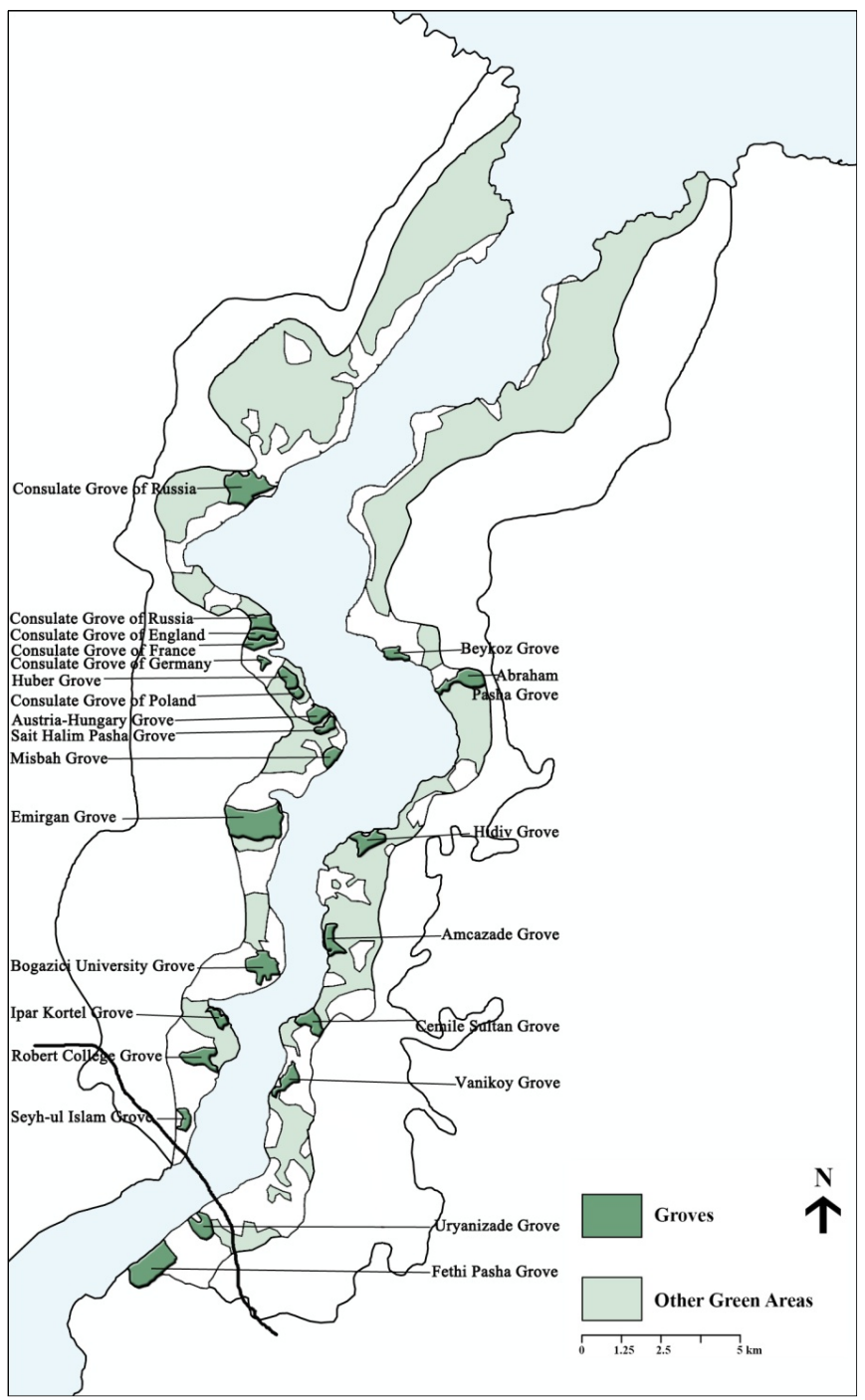

Figure 5: $\quad$ Land use map, 1983.

Conducting protection studies in a growing coastal city locating on two peninsulas are challenging. Protection versus development concerns controversies as in the construction of Second Bosphorus Bridge at 1988. Figure 6 represents the dispersion of groves within 2015 dated Bosphorus area with its two bridges.

Although Bosphorus is a protected area, urban development poses a threat to the groves Villa-style residential areas for high-income groups, illegal settlements of immigrants and densification of the existing built-up space diminish the green structure gradually due to the existence of amnesty laws and conflicts between different laws and plans [7, 9-11]. 


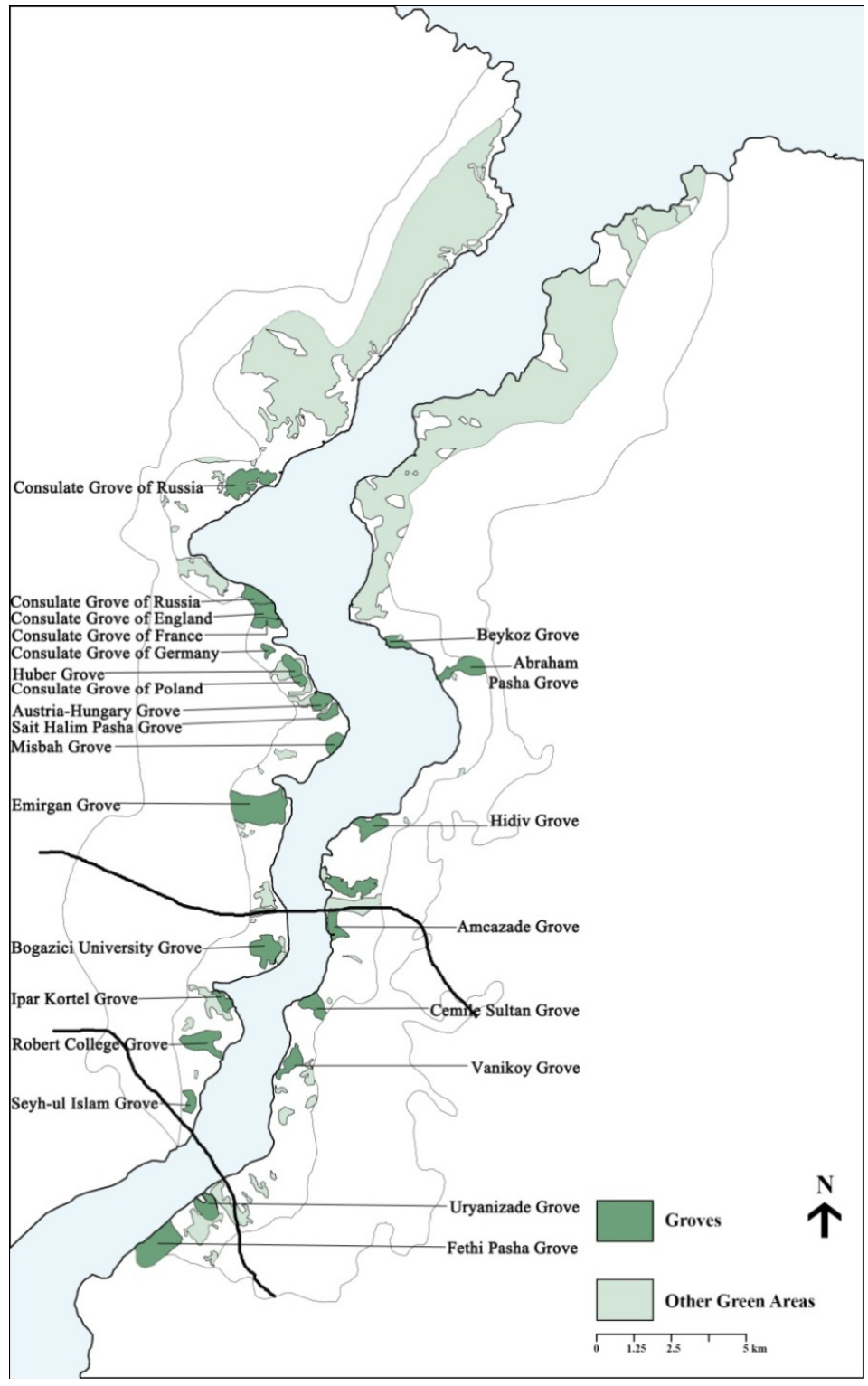

Figure 6: Land use map, 2015.

Protection measures relevant to groves more or less enable these green areas' stability. Due to this stability and quantitative properties, groves have a capacity to act as the hubs in the green infrastructure concept. Thanks to the topography of the Bosphorus area, it is possible to create corridors within the hubs by benefitting from the watercourses, surface water flow areas and transportation lines enabling alley trees. 
Continuity of the green structure does not only cover quantitative issues but the qualitative ones. Therefore, continuity of existing vegetative character of the Bosphorus silhouette is important for both the perceptible landscape and natural habitat integrity.

There is an evident difference between perceptible landscape and map-based landscape. The map-based studies cannot show the Bosphorus' unique topography and its special silhouette, for this reason there is a need for three-dimensional studies and vantage point analysis for the further studies. Protection of a very small sized green area may be of vital importance due to its elevation and visibility from the silhouette. Such a small green area may act as a corridor for binding hubs and elements of urban memory from the silhouette.

The map-based studies cannot show the Bosphorus' unique topography and its special silhouette, for this reason there is a need for three-dimensional studies and vantage point analysis for the further studies. Protection of a very small sized green area may be of vital importance due to its elevation and visibility from the silhouette. Such a small green area may act as a corridor for binding hubs and elements of urban memory from the silhouette.

\section{Conclusion}

"The task of landscape architecture is the conservation and development of natural and cultural landscape resources, together with their associated meanings and values, for the benefit of current and future generations" [12].

Bosphorus groves constitute an important component of Istanbul's green heritage. This study underlines the problems relevant to their spatial and conceptual protection in such a developing city. However, these green areas constitute a great potential for carrying the natural and cultural landscape values of this city to future generations.

By the coordination of administrative, multi-scale and multi-disciplinary studies, it is possible to obtain the continuity of these green heritages. With their hard and soft landscape elements, these areas belong to urban memory. Therefore, protection of these green heritages together with their associated meanings and values is essential rather than only spatially protecting them.

This study is an attempt to for further studies on green heritage's planning and design in the cities where the interplay between protection and development is challenging.

\section{References}

[1] Turer Baskaya, F. A., Revealing Strategies for the Cityscape of Istanbul, EFLA Regional Congress - Mind the Gap, November 02-04, Tallinn, Estonia, (2011).

[2] Retrieved from http://www.ibb.gov.tr/sites/ks/tr-TR/0-Istanbul-Tanitim/ konum/Pages/Nufus_ve_Demografik_Yapi.aspx. 
[3] Eyupreisoglu, M., Istanbul-Bogazici Korularinin Guncel Alan Kullanimi Acisindan Irdelenmesi, Yuksek Lisans Tezi, Yıldız Teknik Universitesi, Istanbul, Turkiye, (2007).

[4] Kilic, H., Bogazici Korularinin Kentici Yesil Alan Sistemi Icindeki Yeri ve Rekreasyon Acisindan Potansiyeli; Dogu Yakasi Korulari: Abrahampasha, Hidiv, Fethipasha, Mihrabat Koruları, Yuksek Lisans Tezi, Fen Bilimleri Enstitusu, Yıldız Teknik Universitesi, Istanbul, Turkiye, (2006).

[5] Dagdelen, I., German Blues: 1913-1914 Before World War Maps of the Istanbul, IBB Kutuphane ve Muzeler Mudurlugu, Istanbul, Cilt 1, p. 103, (2007).

[6] Baytin, C., Turkyimaz, C.C., Kiran, A. and Tunbis, M., Istanbul-Bosphorus as Our Cultural Heritage, The Process of Change Over Time. Proceeding of $9^{\text {th }}$ International CIBA Symposium - New Perspectives to Save the Cultural Heritage, (2003).

[7] Kap, D.S., The Effect of the Legal Arrangements on the Istanbul Bosphorus Landscape Areas and European Landscape Convention as an Opportunity for Restructuring, 1st WSEAS International Conference on Landscape Architecture (LA'08), June 11-13, 2008, Algarve, Portugal, (2008).

[8] GEEAYK/8172,1/5000 Olcekli Bogazici Dogal ve Tarihi SIT Alani Koruma Kararlari, December 14, 1974, Istanbul, Turkiye.

[9] Kozaman, S., Bogazici'nde Siluet ve Siluetin Belirlenmesinde Fotogrametri, Yuksek Lisans Tezi, Fen Bilimleri Enstitusu, Yıldız Teknik Universitesi, Istanbul, Turkiye, (2007).

[10] Salman, S.Y., Bogazici Tarihi SIT Alaninin Yok Olma sureci ve Kalan Sinirli Degerlerin Korunma Olasiliklari, Doktora Tezi, Fen Bilimleri Enstitusu, Istanbul Teknik Universitesi, Istanbul, Turkiye, (2004).

[11] Akdeniz, H., Bogazici'nin Planlama Boyutu ve Yapilasma Sorunu. Harita Dergisi, Harita Genel Komutanligi. (1998), Retrieved from http://www.hgk.msb.gov.tr/images/dergi/makaleler/119_5.pdf, (visited on 01.01.2015).

[12] Bell, S., Sarlov Herlin, I., Stiles, R., Introduction: landscape architecture in a changing world. In: Bell, S., Sarlov Herlin, I., Stiles, R. (eds) Exploring the Boundaries of Landscape Architecture. Routledge Taylor and Francis Group, London and New York, pp. 1-12, (2012). 